\title{
Predikante opleiding: Roeping, keuring en legitimering
}

M Nel

(Universiteit van Pretoria)

\begin{abstract}
\end{abstract}
\section{Training of Pastors: Calling, Testing and Ordination}

The profession of being a pastor is under pressure. The challenge for churches and seminaries is to rediscover what it means to be called, and more specifically to be called for full time ministry in a local church. Such a calling needs to be secularised in order to be recovered. In this process the "job" of the called one needs to be determined, at least to a larger extent, by the congregation or parish. The point in question here is the fact that such "functions" as pastors are being given by God for equipping the body (Eph 4:7-16). When this is a reality, testing for such a call asks for a commitment to what the call, training for the profession and retaining status imply. Such testing leads to new freedom and the discovery of the complex nature of ministry on the one hand, and giftedness for specific ministries on the other. While further research is needed, the intermediate questions are whether there are seminaries that are willing to partner with churches to find an answer to the growing gap between professional training and church-based-training, and whether there are churches with the courage to take recruitment, testing, and ongoing training more serious.

\section{INLEIDING}

Teologiese opleiding en die predikante beroep as sodanig is toenemend onder druk. Schaller (1994:21) skryf:

"From the perspective of the year 2018, perhaps the most far reaching bad news is the inability of today's theological seminaries to attract adequate numbers of highly competent, exceptionally gifted, deeply committed, and clearly extroverted adults born after 1965 who possess a compelling call to parish ministry....The time has arrived for a new system for enlisting, training, screening, and credentialing the next generation of parish pastors".

Kew en White (1997:47) waarsku: soos wat opleidingsentra die postmoderne werklikheid ervaar, moet "risk-taking" deel van hulle bestaanswyse word, of "they are likely to go the way of the dinosaur".

Die doel van hierdie artikel is nie om die "nood" binne die predi- 
kantekorps te bespreek nie. Daar word langs ander weë daarop ingegaan. Die onlangse artikel van Böhmer en Spangenberg (2001:6-14) beklemtoon weer eens (en met goeie verwysings na ander literatuur) die behoeftes (of is dit nood?) binne hierdie beroepsgroep (vgl ook Van Nijen 1993:42-56; Barna 1998:29; Roux 2000:52-53). Die doel van hierdie artikel is om 'n gesprek, met die oog op verdere persoonlike navorsing deur die skrywer, te begin oor roeping, keuring tot opleiding en die konsekwensies daarvan vir legitimering.

Hierdie navorsingsgesprek hou ten nouste verband met die nuwere insigte in die ekklesiologie en die vakgebied gemeentebou. Die navorsing van Gibbs (2000) waarna in hierdie artikel meermale verwys sal word, toon hierdie verband duidelik aan. Hierdie gesprek oor die selfverstaan van die kerk vind plaas binne die ruimte van ander gesprekke oor:

- rasionaliteit in die teologie (vgl Van Huyssteen 1993; 1999);

- die verstaan van identiteit (vgl onder andere de Roest 1998; Burger 1999);

- globalisering (vgl maar net Stackhouse \& Browning 2001) en

- die verstaan van die vakgebied Praktiese Teologie (vgl Pieterse 1993; Heitink 1993; 1994; 1995; 1999).

\section{ROEPING}

\subsection{Die verstaan van roeping}

Wat presies beteken dit om tot die bediening in " $n$ gemeente geroep te wees? Die antwoord op hierdie vraag is nie eenvoudig nie. Van die antwoord hang egter die verstaan van keuring, opleiding en legitimering af. Hierdie roeping is dikwels deur predikante en lidmate eensydig as roeping tot prediking verstaan (Shelley 1989:7-8: Wiersbe 1995:8; Nel 2000:99-102). Intussen het die teologie van die lidmaat binne die vakgebied gemeentebou hierdie verstaan van roeping uitgedaag en verander. Gibbs (2000:108-109) stel tereg dat die huidige en toekomstige pastors "must have the ability to wear different hats". Van hulle word verwag om 'n verskeidenheid van rolle te vervul:

- "caring for members at every stage of life...

- to be preacher...

- teacher...

- evangelist...

- managers of institutions...

- leaders of the total enterprise..."

en omdat die meeste gemeentes klein is: 
- "the majority of pastors must function as generalists",

terwyl in groot gemeentes die rol van die senior pastor:

- "entails taking responsibility under God for the spiritual wellbeing of an entire congregation of believers as well as for leading the community into effective ministry in the world" (Gibbs 2000:109).

\subsection{Die verband waarbinne roeping verstaan word}

Die nadenke oor die roeping van ' $\mathrm{n}$ predikant/leraar/pastor moet in breër perspektief geplaas word. Die roeping van 'n predikant/leraar/pastor behoort in ' $\mathrm{n}$ sekere sin gesekulariseer te word, om daarna herinterpreteer te word. Alle mense is geroep tot 'n beroep. Ongelowiges erken en bely dit net nie. Dekker (1996:13-21) toon aan hoedat die godsdiens aanvanklik die verstaan van arbeid beïnvloed het (vgl ook Marshall 1991). Arbeid dra vir baie jare reeds 'n puriteinse verstaan daarvan: arbeid is 'n deur God gestelde taak. "Der Puritaner wollte Berufsmensch sein, - wir müssen es sein" (Weber 1920:63,203). Die Duitse en Afrikaanse woorde ("Beruf" en beroep) dra steeds iets van hierdie verstaan van arbeid. Binne die Gereformeerde tradisie vind hierdie verstaan ook neerslag in die belydenis (HK Sondag 49). In die woorde van die klassieke etikus Brillenburg Wurth (1951:257-258): "God doet in Christus op ons Zijn goddelijk beroep, God vordert in Christus ons op, om ook in onze dagelijkse bezigheden Hem te dienen". Die sosioloog Wuthnow (1992:69) skryf dat byna die helfte van getroue kerkgangers in die VSA die gevoel het dat God hulle tot hulle werk geroep het.

In die ontwikkelende kultuur van die sekularisme verloor die "godsdiens" sy greep op die arbeid. Godsdiens word steeds meer teruggedruk tot die persoonlike lewe. Die lewe word uitmekaar gehaal, en godsdiens as die integreringsprinsipe ontbreek almeer. Die godsdiens trek sigself almeer terug uit die samelewing en word algaande "verkerklik". Kaufman (1979:101) se tese is dat die sekularisering van die samelewing ooreenkom met die verkerkliking van die Christendom. Hierdie perspektief behoort in die huidige debat oor die kultuur, en die verdwyning van die era van die Christendom, 'n rol te speel. Die Christendom verdwyn in die verkerkliking van Christelike godsdiens. In die proses vervreem die mens, en veral die kerkmens, van die samelewing. Dekker (1996:35) verwys na Zijderveld (1971:71-72) se opmerkings dat die moderne samelewing abstrak word in die ervarings van die bewussyn van die mens. Dit lyk of arbeid slegs nog as roeping verstaan en gemoti- 
veer word waar godsdiens wel die integreringsprinsipe is. Waar arbeid roeping en plig is, waar sowel die "lustenkarakter" as die "lastenkarakter" van arbeid ernstig geneem word, is arbeid 'n teken van die Koninkryk wat gekom het en komend is. "Wie arbeid als roeping beleeft, heeft een missie" (Jongeneel 1994:110).

Ook die predikant/leraar/pastor behoort arbeid as sodanig as roeping te verstaan. Binne die herevaluering van roeping is hierdie sekularisering nodig. Roeping is nie sakraal-kerklik nie. Roeping het te doen met God en sy wêreld. Terwyl hier toegegee word dat die komplekse karakter van die huidige arbeidsbestel nie beskryf is nie, word samevattend aangesluit by 'n slotopmerking van Dekker (1996:75): die arbeidsbestel kan die "Integratieve en dwingende instantie in onze samenleving" wees.

Dit is het middel teen chaos geworden; dat is hét middel tot integratie, tot participatie in de samenleving en daarmee het middel om op een sociaal aanvaardbare manier te leven. In die zin heeft het arbeidsbestel de functie van de traditionele godsdienst overgenomen. Het hemels baldakijn is een sociaal baldakijn geworden. Ook die predikant/leraar/ pastor is 'Berufsmensch' - wir müssen es sein (Weber).

Wanneer dit gebeur met gelowiges (uit wie God ook beroepsmense vir die voltydse bediening in die gemeente roep), mag geslaag word in ' $\mathrm{n}$ poging om roeping tot predikant/leraar/pastor te herontdek. Die bedoeling is om die belang van arbeid en die belang van die totale bediening te herontdek. Juis hierdie totale benadering plaas nie alleen die herinterpretasie van roeping tot predikant/leraar/pastor in perspektief nie, maar ook ' $\mathrm{n}$ verstaan van ' $\mathrm{n}$ roeping tot afsonderlike bedieninge.

Enige roeping tot voltydse bediening in " $n$ gemeente het verfyning nodig. Dit gaan om plekvinding, in ooreenstemming met gawes en opleiding, binne die totale bediening. In ' $\mathrm{n}$ gemeente met slegs een predikant/leraar/pastor is dit natuurlik moeilik. ' $\mathrm{n}$ Kontekstuele verpligting tot alle vorme van bediening verander nog niks aan die beginsel nie. Roeping tot voltydse bediening, " $n$ roeping tot alle vorme van bediening in die gemeente, impliseer nie uitmuntendheid in elke vorm van die bediening nie. Dit impliseer hoogstens verpligting, vanweë die situasie, tot al die vorme van bediening wat deur die situasie vereis word. In die geval waar die "ek" die enigste een is, moet "ek" byvoorbeeld preek. Dit beteken nog nie dat "ek" kan preek nie, en dat dit my beste bydrae tot die totale bediening is nie.

\subsection{Herinterpretasie}

Herinterpretasie van roeping het met alles wat hierbo bespreek is, te doen. Roeping en beroep lê ook in die lewe van 'n predikant/leraar/ pastor naby aan mekaar. Skerp mag die twee in elke geval nie geskei word nie. Binne die Reformatoriese tradisie is elke beroep tegelyk ook 
roeping. Die bedoeling is om die geroepenheid tot ' $n$ beroep te onderskei en uit te lig. Juis dit maak die verskil in die beoefening van dit waartoe die predikant/leraar/pastor in sy/haar beroep geroep is. Insig in wat roeping beteken, maak die verskil of die predikant/leraar/pastor soos gewonde "diere" wandel en ander wond, en of sy/hy "wounded healer(s)" word (vgl Nouwen 1972; Wimberley 1997:133-142). Dit vra na 'n voortdurende en gesonde herevaluering van roeping. Wimberley (1997:1-13) noem dit: "to be called anew...". In die woorde van Osmer (1990:141 ev) kom dit neer op "discover" ten einde te "recover". Hy sê tereg dat die herontdekking ("rediscovery") van 'n tradisie nie dieselfde is as die herstel ("recovery") van 'n tradisie nie (vgl ook Shawchuck \& Heuser 1993). Die geroepene moet meermale sy roeping terugroep. Rogers (1989:19-23) verwys in hierdie verband na 'n "remembered call" en 'n "renewed call".

Die verhouding met die Een wat roep, is in hierdie verband krities. Nel (1999:22) maak die stelling dat niks in die lewe van 'n mens gebeur nie totdat jy glo en beleef dat God 'n persoon is, dat Hy leef, dat ons verhouding met Hom in Christus deur die Gees herstel is, en dat ons in 'n intieme verhouding met Hom leef. Die gelowige is in verhouding met Iemand en nie met iets (soos godsdiens of 'n beroep) nie. Hierdie verhouding is die verskil. Hierdie insig is krities om te vermeld vanweë die rol wat dit in die herinterpretasie van roeping speel.

In hierdie verband is dit nodig om te verwys na die totale verandering in die verstaan van die kerk wat in die samelewing plaasgevind het en steeds plaasvind. Meer en meer word die gemeente herwaardeer as beweging van dissipels van Jesus Christus. Om dit 'n oomblik in die taal van die geskiedenis te sê, en in terminologie waarvan (minstens in Afrikaans) wegbeweeg word, dit is 'n leke beweging. Dit is hierdie ontwikkeling wat lê agter 'n nuwe belangstelling in die gemeente as basis vir teologisering en selfs van teologiese opleiding (vgl Elliston 1995:8-10; Theron 1995:45-56; Gibbs 2000:99). Dit is nie hier nodig om die lang pad en stryd agter die ontwikkeling te skets nie. 'n Paar artikels in hierdie verband lewer genoegsame bewys van die gawe en opgawe. Weber (1991:118-122) verwys na die ou spanning binne die kerk tussen lidmaat en pastor en hoe die lidmaat eintlik in belang van die bediening van die "Pfarrer" beklemtoon was (nog is?). Die spanning met die volkskerklike mentaliteit en strukture (in belang van instandhouding) word deur Herrmann (1994:468-476) uitgelig in 'n artikel onder die opskrif: "Patient Kirche". Hans-Richard Reuter (1996:33-50) se mening oor die dienste van die gemeente is " $\mathrm{n}$ goeie voorbeeld van talle ander oor die "diakonische Gemeinde" (vgl ook Winkler 1993:205-209). Raiser (1993:375383) en Neely (1993:152-161) se bydraes lê dieselfde verband, maar in ekumeniese konteks bevestig dit dieselfde ontwikkelinge. Enkele artikels 
in Nederland bevestig dit ook en gee insae in die bekendste literatuur (vgl Hendriks 1994;1995; Schippers 1994; Dingemans 1994). In SuidAfrika is publikasies in hierdie verband goed bekend (vgl Nel 1987; 1988;1994; Hendriks 1992; Burger 1991;1999).

Gibbs (2000) verwoord die dringende veranderinge wat in die roeping tot voltydse bediening nodig is, treffend. Hy praat daarvan as veranderinge:

- "from living in the past to engaging with the present" (13-35);

- "from market driven to mission oriented" (36-64);

- "from bureaucratic hierarchies to apostolic networks" (65-91);

- "from schooling professionals to mentoring leaders" (92-119);

- "from following celebrities to encountering saints" (120-145);

- "from dead orthodoxy to living faith" (146-171);

- "from attracting the crowd to seeking the lost" (172-192);

- "from belonging to believing" (193-216);

- "from generic congregations to incarnational communities" (217-239).

In die geval van die predikant/leraar/pastor behoort die verstaan van roeping te verander tot die verstaan van 'n beroep met hoë risikos. Opleiding word dan die noodsaaklike voorbereiding vir 'n "high-risk mission" (Gibbs 2000:97). Die verstaan van die missionêre identiteit van die kerk verplig die predikant/leraar/pastor hiertoe. Die missionêre gemeente verstaan die dinamiese verhouding tussen kerk, evangelie en die samelewing. Hier is geen gemaksone waar onbekostigbare luukshede in stand gehou word nie. Die gemeente wat homself so verstaan, is inderdaad 'n "at risk community". 'n Hele nuwe stel reëls geld vir diegene wat die missionêre gemeente tot doelvervulling begelei en versorg (vgl Callahan 2000:31 ev).

\subsection{Gemeente en roeping}

Die gemeente as teologies-sosiologies werklikheid speel waarskynlik nog nie sy regmatige rol in die bepaling van die roeping van diegene wat sê dat hulle tot die beroep van voltydse predikant/leraar/pastor geroep is nie. Wat binne die gemeente behoort te gebeur, bepaal immers die werk van die predikant/leraar/pastor. Die gemeente gee inhoud aan die beroep van die geroepene. Deeglike eksegese van byvoorbeeld 'n klassieke gedeelte soos Efesiërs 4 bevestig dat die inhoud van die "gawes" van besondere funksies bepaal word deur die gemeente en sy opbou (vgl Roberts 1983). Literatuur oor "church based training" gee toe dat hierdie opleiding onvoldoende is (vgl weer Elliston 1995:8-10). Gibbs (2000:99) sê tereg: "they are in danger of being so competency-based that they fail 
to provide theological and missiological foundations and critiques to ensure that the growth they seek to enhance is authentic and substantive in terms of kingdom values". Wat wel erken word, is die rol van die gemeente en sy behoeftes in hierdie opleiding. Die gemeente speel 'n deurslaggewende rol. Die behoefte word gevoed deur die "painful personal disappointments" (Ellison 1995:8) en die "frustration churches feel with seminaries that are more closely identified with the academic and scholarly pursuits than with the churches and their pressing needs" (Gibbs 2000:99). Die ideaal is samewerking tussen opleiding en gemeente. Hierop word nie nou hier ingegaan nie. Die doel is om hier te beklemtoon dat die "werkgewer" (in hierdie geval die gemeente en die kerkverband), die reg het om die beroep wat hier beoefen word, met inhoud te vul. Wie hom/haar hiertoe geroepe weet, weet dan meteens ook wat haar/sy beroep inhou en wat die eise aan die beroep en die voortgesette beoefening daarvan inhou. So iemand weet wat opleiding tot en voortgesette opleiding binne die beroep beteken. Dít is die beroep, dít is die vereiste opleiding en dít is die voortgesette opleiding vir iemand wat in die beroep wil bly. Ek is saam met Gibbs (2000:94) oortuig dat "local churches need to play a far more active part in recruiting and mentoring individuals they deem suitable for receiving further training". Die normale ontwikkeling binne die paradigma van teologisering binne plaaslike gemeentes behoort te wees dat meer ouer persone deur die gemeentes vir opleiding tot die bediening aanbeveel te word. Persone wat pas na skool vir teologiese opleiding aanmeld, is nie vanselfsprekend materiaal vir die voltydse bediening in gemeentes nie. Kerke en opleidingsinrigtings sal saam moet besin oor hoe hierdie groep studente hanteer behoort te word.

\subsection{Samevattend}

Samevattend kan gestel word dat roeping tot voltydse bediening in ' $\mathrm{n}$ gemeente inhou dat die geroepene:

- sy/haar beroep as vervulling van lewensdoel as skepsel verstaan;

- gewillig is vir en verbind is tot dit wat in hierdie beroep vereis word, hoe omvattend en veeleisend en riskant dit ook al mag wees (daar is ander minder riskante beroepe wat net soseer roeping van God is);

- die eis en implikasies vir opleiding tot en opleiding in en gedurende die beroep as wesenlike eis vir die voortgesette beoefening van die beroep aanvaar (lewenslange leer); en

- lewenslange evaluering as deel van die voorreg om hierdie beroep te beoefen, erken en verbindend aanvaar. 


\section{KEURING}

\subsection{Sensitief, maar nodig}

Waarom is keuring vir die bediening so 'n sensitiewe probleem? Waarom word hierdie roeping verhef bo dié van ander gelowiges wat tot die mediese wetenskap, tot die onderwys, ensovoorts geroep is? Gaan dit basies terug op misverstande rondom die werk van die Heilige Gees? Het kerke ook in die verstaan en onderskeiding van die wil van Here die rol van die gemeente gering geskat? Osmer (2001:37-75) se menings oor die onderrigtaak van die kerk in 'n multikulturele wêreld, en sy verstaan van die didache dui beslis in hierdie rigting. Een van die "perennial tasks" van onderrig is onderskeiding (2001:59-61). Die rol van die gemeenskap van die gelowiges is in hierdie verband opvallend (vgl Matt 12;16; Rom 12): "in all of its ministries, the church invites its members to engage in this activity. The teaching ministry, however, has the special task of preparing the members of the Christian community to engage in the discernment which other forms of ministry evoke" (Osmer 2001:61; 1990). Nel (2001:13-16 met besondere verwysing na Van Ruler 1963 \& 1973; Firet 1977; Van der Geest 1981) het probeer aantoon dat die belydenis van die Heilige Gees as soewereine bewerker van die heil (wat God in Christus skenk) nie beteken dat God die mens uitskakel nie (vgl ook Vos 1996). Hoe meer ons van die Gees verstaan, hoe meer verstaan ons dat ons ingeskakelde mense is: God werk in die mens en deur die mens. Die Gees werk in die ganse skepping en in die herskepping van alle mense (en beroepe). Hierdie erkenning skakel enige beroep op Hom uit wanneer gepoog word om die beroep van die predikant/leraar/pastor van normale beroepseise en -voorwaardes uit te sluit.

En tog: om aan hierdie faset van die wording van 'n predikant/ leraar/pastor te raak, is om 'n stok in 'n bynes te steek. Om baie redes is dit inderdaad sensitief. Elke skrywer moet vir hierdie sensitiwiteit respek hê. Elke predikant/leraar/pastor wonder van tyd tot tyd waar sy/hy sou wees indien "ek getoets" was. Gelykwaardige respek vir die gemeente as die duur gekoopte mense van God in Christus dwing die skrywer om ook aan die ander kant te wonder: hoort ons almal in die bediening en hoort ons almal op kansels? Mag die kerkverband toelaat dat 'n gemeente aan "my" bediening en prediking (as deel daarvan) blootgestel word?

My oortuiging hiervan het oor jare heen, onder andere om laasgenoemde rede, ten gunste van toetsing gegroei. Die vraag is hoe, wanneer en waar? Die bydrae in hierdie publikasie is nie soseer oor die tegniese vraag na die betroubaarheid van toetsing nie. Die versoeking is in hierdie geval om oor moontlike gevare en wat nog meer te praat sonder om ooit die werklike saak ter tafel te neem: kan kerke langer so voortgaan? Is die enigste manier om uit te vind of die bediening my "beroep" is die weg 
van "trial and error"? Kan daar eers aan die einde van iemand se bediening gesê word dat hy/sy in hierdie beroep gehoort het? Kan daar eers na die hoeveelste fout in die teater wat tot dood gelei het, uitgevind word dat iemand nie 'n chirurg behoort te wees nie? Hoeveel kinders moet dieselfde vak druip voordat iemand uitvind: ek is nie 'n onderwyser nie? Speel die ontvanger nie ' $\mathrm{n}$ belangriker rol as om as proefkonyne te dien totdat iemand hom- of haarself as predikant of nie-predikant bewys nie? Om van die skade aan die persoonlikheid van die betrokkene nie eers te praat nie! Binne die Reformatoriese tradisie word die werk van die Heilige Gees nie só verstaan nie.

\subsection{Keuring is bevrydend}

Die bedoeling is om enkele waarnemings en insigte te deel wat mense kan help om gemakliker aan toetsing deel te neem, in belang van pastorale vreugde, lewensvervulling en bevestiging van identiteit. Ek is oortuig dat ' $\mathrm{n}$ roeping tot die bediening nie noodwendig " $\mathrm{n}$ roeping tot predikant wees insluit nie. Insigte soos hierdie behoort bevrydend te wees. Keuring moet hiermee rekening hou. Almal wat as geroepe aanmeld vir opleiding, moet insig kry in hoe roeping tot en begaafdheid vir die bediening met mekaar verband hou. Daar is dan ook nie die moontlikheid om die toets te "druip" nie. Toetsing word dikwels so beleef, mis kien omdat prediking selfs in die bewussyn van diegene wat toets te prominent is. Dit kom kortliks en in eenvoud hierop neer:

- wat beteken my roeping tot die bediening in sy wyd geskakeerdheid;

- indien die roeping primêr verstaan word as "werk met mense", is die basiese insigte en begaafdhede hiervoor teenwoordig?;

- aangesien die bediening ook prediking as prominente deel insluit, in watter mate is die gawes van en vir publieke kommunikasie daar?

- indien nie, watter ander weë van konstruktiewe en kreatiewe deelname aan die koms van die Koninkryk is beskikbaar?

Aangesien sommige persone nog direk na skool vir hierdie "beroep" aanmeld, is dit byna logies dat hierdie toetsing herhaal moet word, en ontwikkeling in ag geneem moet word. Mense groei en ontwikkel. Wat hier byna belangriker is, is ' $\mathrm{n}$ verbintenis van die toekomstige werkgewers om sy toekomstige werknemers te laat verstaan wat hierdie "werk" vereis (sien 2 hierbo). Die angel kan uit die saak gehaal word deur vir eens en vir altyd te aanvaar dat ons in die beroep van 'n predikant/leraar/ pastor na spesifieke kwaliteite soek.

Impliseer dit dat daar 'n tipiese profiel vir 'n predikant is? Is en 
moet almal eenders wees? Waarskynlik nie, maar dit is nie die punt nie. Die punt is dat die predikant/leraar/pastor in 'n mens-beroep staan, en mens-beroepe, in diens van God (soos aangeneem word), vra na mense wat met ander mense kan werk. Dit is 'n eensydige rasionalisering om later in die bediening, wanneer iemand in leierskapstoetse hom/haar byna uitsluitlik as saak-gerig uitwys, te beweer dat die gemeente ook sodanige mense nodig het. In meerdere bedienings kan iemand dan nog daarmee wegkom, want per grasie Gods is daar gewoonlik ook een van die span wat met mense kan werk. Die Here het genoeg sogenaamde saak-gerigte kinders in sy gemeente. Hy skenk mense as gawes om mense met gawes voor te berei vir hulle diens - wat daardie diens ookal mag wees.

Die bedoeling met keuring en toetsing is "toetsing tot bevryding" vir die diens waartoe ek gebore, begenadig (begaafd) en voorberei is. Hierdie toetsing en keuring moet uiteraard psigologies en teologies van aard wees. Die kritiese vraag is egter hoe ernstig die werkgewer in hierdie verband is. In die nuwe situasie, waar die kerkraad (gemeente) die werkgewer is, moet in elk geval opnuut gewerk word aan 'n nuwe verstandhouding tussen die kerkverband (as verantwoordelik vir opleiding) en die werkgewer, die gemeente (as kliënt). Die kerkverband is in hierdie opsig te eensydig gelaai met diegene wat werknemers van die gemeentes (vir wie se diens opgelei word) is. Werknemers kan nie eensydig besluit oor wat die werkgewer, die gemeente, nodig het en verlang nie. Dit bots nie alleen met beginsels in arbeidsreg nie, maar is teologies ook nie regverdigbaar nie. Waar dit so is, is dit waarskynlik nog 'n oorblyfsel van ' $n$ tyd in die kerklike lewe waar gemaklik geredeneer is dat predikante gemeentes het. In gemeentebou is dit agterhaald: gemeentes het predikante. Die predikante is gawes aan gemeentes. Laasgenoemde is die primêre grootheid. Hulle is vir diens voorberei: die erediens, die diens aan mekaar, en die diens aan die wêreld! (Vir enkele suggesties oor hoe hierdie toetsing en keuring kan gebeur vgl Nel 2001:119-132).

\subsection{Blootstelling en evaluering}

Blootstelling aan ' $\mathrm{n}$ gemeente is ' $\mathrm{n}$ toets. Dit toets meer as vaardighede. Dit toets ook hoe die predikant/leraar/pastor inpas in dit waarvan hy/sy oortuig is dat dit "my" roeping is. In die gereformeerde benadering is daar nog altyd baie gemaak van die uitwendige roeping as bevestiging van die inwendige roeping. Soveel so dat sommige persone byvoorbeeld selfs die oorskot van proponente in die Ned Geref Kerk te gemaklik toeskryf aan 'n teken dat God nie die inwendige roeping met 'n uitwendige bevestig nie. So eenvoudig is dit net nie. Daar is baie ander faktore wat op so 'n situasie inspeel.

Hierdie blootstelling mag nie lukraak aan wisselende faktore oor- 
gelaat word nie. Die kerk kan tog nie aanvaar dat wanneer 'n gemeente student $X$ beroep, en dit werk net nie uit nie, daardie gemeente as't ware die blootstelling en toetsing vir die kerk moes doen nie. En om alles weg te verklaar as "daardie gemeente het al ander voor haar ook gebreek"; "dit is 'n moeilike afskop vir enige jongman"; "sy sal nog leer"; "almal maak maar foute in hulle eerste gemeentes", ensovoorts, gaan in 'n Reformatoriese tradisie nie op nie. Mediese studente oefen op kadawers, want hulle mag onder geen omstandighede op die lewende pasiënt oefen nie. Hoe word teologiese studente blootgestel en evalueer? Waarskynlik deur baie meer blootstelling onder toesig in die klas, maar ook buite die klas. Die sisteem van ' $n$ gemeentejaar in sommige denominasies en die vikariaat sisteem in ander is pogings tot blootstelling en verdere opleiding ná blootstelling.

Predikante/leraars/pastors-in-wording moet blootgestel word om hulle kwesbaarheid ("vulnerability") te toets. Mense in Sondag eredienste kom uit 'n week waar talle deur die eise van die lewe vuisvoos geslaan is. Predikers druk dan soms hierdie mense met woorde in 'n hoek vas - terwyl hy of sy self die horlosie wat die lengte van die rondte bepaal, vashou. Hierdie kwesbaarheid (of gebrek daaraan) kan deur blootstelling getoets word. Niemand mag in hierdie verband gespaar word nie. Dit gaan in die voorbereiding van predikante/leraars/pastors vir hulle beroep om die vorming van mense wat weet wie hulle is, en wat om daardie rede met groot versigtigheid omgaan met mense wie se behoeftes hulle dikwels nie eens ken of verstaan nie. God word in die bediening verteenwoordig! Hier pas geen arrogansie nie.

Hoe belangrik hierdie blootstelling as toetsing van roeping en bedoeling is, blyk ook uit 'n bydrae van Pickard (1999:27-38) oor die insigte van Habermas (1984:273-337) rakende kommunikasie. Uit Habermas (1984:285) se bespreking van wat hy noem "strategic action" (:285), blyk dat sodanige aksie in meer as een vorm kan geskied. Die gevaarlikste vorm is "concealed strategic action". Sodanige aksie funksioneer as bewuste of onbewuste misleiding. Laasgenoemde word ook genoem: "systematically distorted communication" (Habermas 1984: 332). Dit het noodlottige gevolge vir integriteit in kommunikasie. Pickard (1999:36) noem dit 'n etiek van "vulnerability". Dit sluit naamlik aan by Freud se teorie van die onderbewuste en onderdrukking van konflikte en lei tot verdedigingsmeganismes en ernstige kommunikasiesteuring, beide intra-psigies en inter-persoonlik (Habermas 1984:332). In so 'n geval het strategiese aksies slegs die skyn dat egte kommunikasie gesoek word. Die tragiese is dat so ' $\mathrm{n}$ distorsie in kommunikasie nie bewustelik bedoel word nie, maar wel 'n werklikheid is.

Daar is waarskynlik geen waterdigte manier om "jouself" en ander te help om blootgesteld te word, te wees en te leef nie. Wie ken hom- of 
haarself ooit ten volle só? En tog, hoe moeilik ookal, blootstelling en evaluering kan meewerk tot selfontdekking en genesing van enigiets wat ons kommunikasie belemmer en verhinder

Wie nie weet wat om te doen nie; wie nie weet hoe om wat te doen nie dra onsekerheid in sy eie lewe en persoon in. Die wie kom dan self in die gedrang. Tereg merk Jackson (1974:35) op: "competence and trustworthiness are frequently not perceived as being equally present in the same person... a minister ought to determine his relative strength and weakness in these two dimensions" (vgl ook die uiters belangrike bydrae van Demaray (1990:13-41) in hierdie verband).

Brooks het dit reeds binne sy definisie van prediking raakgesien en erken: As prediking "truth through personality" is, dan lê die onderskeiding van goeie en swak prediking op hierdie vlak: waarheid alleen mis persoonlikheid en persoonlikheid alleen mis waarheid: "It is in the different proportion in which the two are mingled that the difference between two great classes of sermons and preaching lies" (Brooks 1964:5). Brooks (1964:9) se verwysing na opleiding is in die verband van hierdie artikel belangrik: "What is preparation for the ministry? It must be nothing less than the making of a man... It must be nothing less than the kneading and tempering of a man's whole nature till it becomes of such a consistency and quality as to be capable of transmission... Everything that opens their lives towards God and towards man makes part of their education... Professional training is a real part, but a small part". (Dit is byna logies dat Brooks, as kind van sy tyd, in sy opmerkings net na die manlike persoon verwys).

Dit is noodsaaklik om vir die jare wat voorlê leiers op te lei. Die leiers wat nodig is, wel risikos kan neem, agente vir reformasie en transformasie wees, en kan rigting aandui en vordering moniteer. Gibbs (2000:107) verwys na 'n ondersoek van Barna (1997) waar slegs 5\% uit 601 pastors aandui dat hulle hulleself as leiers sien. Van die baie vrae wat hieroor gevra kan word, is: is dit die keuringsproses wat persone met leierskap inisiatiewe uitskakel? Oorweeg leierskap tipes nie hierdie bediening nie? Voeg ook by die verstaan van spanwerk, en watter rol opleiding daarin speel. Schaller (1995:62-64) vestig die aandag op die tekort aan "gifted, cohesive and productive staff teams in local churches". Hy en Gibbs (2000:107) dink dat die manier waarop persone opgelei word "reinforces an independent and individualistic mindset". Schaller (1995:63) beskou dit as uitvloeisel daarvan dat die teologiese opleiding (soos alle ander opleiding) "individualism, self-reliance and individual performance" baie hoog aanslaan: "Theological seminaries are designed to welcome persons who have excelled in an academic environment that rewards individualism and trains students to go out and function as individuals, not as members of a team". Miller (1997:188) 
argumenteer dat tradisionele kerke en opleidingsinrigtings dikwels demotiverend is vir persone met buitengewone leierskapsvaardighede.

Hoewel dit in bogenoemde reeds veronderstel is, is dit van soveel belang dat dit weer beklemtoon moet word: predikante/leraars/pastors het besondere opleiding in die analise van die gemeente en sy konteks nodig. Alle teologiese dissiplines behoort die inklusiewe karakter van die bediening ernstig te neem. Die vakgebied gemeentebou trag om die geheel, waarvan die dele belangrik is, voor oë te hou. Om die gemeente as sisteem te verstaan, om die sub-sisteme binne die geheel te verstaan, om die gemeente as sub-sisteem binne die sisteem van die betrokke samelewing te verstaan, is geen geringe opgaaf nie (vgl Parsons \& Leas 1993; Armour \& Browning 1995). Teologiese opleiding gaan nie met minder as hierdie inklusiewe denke en verstaan van die werklikheid wegkom nie. Die besondere bydrae van ' $n$ bekende homileet soos Killinger (1995) en sy ontleding van die situasie van en prediking in die "hoofstroom" kerke beklemtoon dieselfde. Dit is noodsaaklik om die denkraamwerk van die mense van ons tyd te verstaan en ernstig te neem. Sy aanbevelings oor prediking in "die laaste dae van die hoofstroom kerke" bepleit opvallende eenvoud. Die ontleding van die samelewing is wel intens kompleks, maar noodsaaklik. Killinger (1995:78) suggereer byvoorbeeld dat "preachers today make huge efforts to patiently clarify for their parishioners the real nature of the culture shift we are in and how it affects their faith and their church, and to do so from the most comprehensive biblical and cultural positions it is possible to occupy". Miskien is een van die dringendste behoeftes in teologiese opleiding " $n$ empiriese benadering tot die teologie en praktiese teologie in besonder. Sosiologie behoort byna verpligtend te wees (vgl ook Morris \& Olsen 1997; Hawkins 1997).

\section{LEGITIMASIE}

Wat is die implikasies hiervan vir die legitimering en ordening van teologiese studente? Meer navorsing is nodig voordat hieroor duideliker aanbevelings gemaak kan word. Wat voorlopig ernstig op die tafel is, is die volgende:

- Nie almal wat vir teologiese opleiding aanmeld, hoef vir aanmelding tot die voltydse bediening in aanmerking te kom nie. Volgens Gibbs (2000:101,108) word (minstens in die VSA) die persone wat aanmeld vir opleiding ouer. Diegene wat direk na skool as geroepenes aanmeld, word in werklikheid slegs opgelei op die basis van hulle toekomstige (ongetoetste) potensiaal. Hulle opleiding is nie op grond van reedsbestaande (bewese) en operatiewe bedieningsgawes nie. Enige student is welkom om 
teologie as opleiding te kies, maar dit moet nie vanselfsprekend wees dat hier 'n voltydse predikant/leraar/pastor-in-wording is nie. Hierdie studente is daar (en is so kosbaar soos enige ander student in enige ander fakulteit) "due to their having fulfilled the academic entry requirements, but without any assessment of their sense of call to the ministry, their suitability or their individual gifting" (Gibbs 2000:101).

- Van die persoon wat vir opleiding met die oog op voltydse bediening as predikant/leraar/pastor aanmeld, moet vereis word om hom/haar te vergewis van die omvang van die beroep, die opleiding, en wat die vereistes is om in hierdie beroep akkreditering te verkry en te behou. Voortgesette opleiding en evaluering is onverhandelbaar deel van hierdie vereistes.

- Teologiese opleidingsentra moet die leiding neem om die ontwikkelende kloof tussen opleiding en bediening te oorbrug. Gibbs (2000:92-119) en Miller (1997:188) toon oortuigend aan waarom dit krities belangrik is vir die toekoms van opleiding en kerk. Om dit in enkele van Miller (1997:188) se woorde te sê: "Seminaries, in contrast (to professional graduate education $\mathrm{MN}$ ) should be professional schools where people are mentored and taught while they serve within local congregations. Learning disconnected from day-to-day practice may be appropriate for those pursuing a $\mathrm{PhD}$ and doing graduate-level research, but I am not certain that it is appropriate for those responding to a pastoral calling. Indeed, I would favor downsizing the physical plant of most seminaries and increase creating 'lay-institutes' on campuses of larger mainline churches".

\section{SAMEVATTING}

Navorsing soos hierbo aangevoor en in die vooruitsig gestel, vra nog verdere besinning. Die noodsaak is dringend. Die vraag is of opleidingsentra in Suid-Afrika nog genoeg tyd het om te reformeer, te herstruktureer en te herkurrikuleer om die ontstaan van teologiese opleiding binne gemeentes te voorkom, te beperk of te bestuur.

'n Tweede vraag waarmee hierdie voorlopige verkenning die leser behoort te laat, is of dit die kerke in hierdie land se erns is om nie langer die sukses van voornemende predikante/leraars/pastors aan "trial and error" oor te laat nie? Watter denominasie het die moed om reformasie hier by een van sy wortels aan te pak? 


\section{Literatuurverwysings}

Armour, M C \& Browning, D 1995. Systems-sensitive Leadership: Empowering Diversity without Polarizing the Church. Joplin, MS: College.

Barna, G 1998. The Second Coming of the Church. Waco, TX: Word.

Böhmer, A C, Spangenberg, J J 2001. Depressie en angs onder predikante van die Nederduitse Gereformeerde Kerk in Wes- en Suid-Kaap. NGTT 42(1 \& 2):614.

Bosch, D J 1991. Transforming Mission. Maryknoll: Orbis.

Brooks, P 1964. On preaching. New York: Seabury.

Burger, C W 1991. Die dinamika van 'n Christelike geloofsgemeenskap. Kaapstad: Lux Verbi.

Burger, C W 1999. Gemeentes in die kragveld van die Gees. Gemeente en bediening 4. Stellenbosch: BUVTON.

Brillenburg Wurth, G 1951. Het christelijke leven in de maatschappij. Kampen: Kok.

Callahan, K L 2000. Small, strong congregations. San Francisco: Jossey-Bass.

Dekker, G 1996. Van roeping naar baan. Arbeid in godsdienstig perspectief. Baarn: Ten Have.

Demaray, D E 1990. An introduction to homiletics. (2 ${ }^{\text {nd }}$ rev ed) Grand Rapids: Baker.

De Roest, H 1998. Communicative identity. Habermas' perspectives of discourse as a support for practical theology. Kampen: Kok.

Dingemans, G D J 1994. Het beginsel van de conciliariteit. Praktische Theologie 21(4):412-421.

Elliston, E 1995. Church Based Training. Global Church Growth 32(1):8-10.

Firet, J 1977. Het agogisch moment in het pastoraal optreden. Kok: Kampen.

-, 1986. Dynamics in pastoring. Grand Rapids: Eerdmans.

Gibbs, E 2000. Church Next. Quantum changes in how we do ministry. Downers Grove: InterVarsity.

Habermas, J 1984. The theory of communicative action. Volume 1. Reason and the Rationalization of society. Boston: Beacon. Vertaal uit die 1981 Duitse uitgawe deur Thomas McCarthy.

Hawkins, T R 1997. The learning congregation. Louisville: Westminster John Knox.

Heitink, G 1993. Praktische Theologie. Kampen: Kok.

-, 1994. Ontwikkelingen in de praktische theologie. Een kroniek. Praktische Theologie 21(5):511-536.

-, 1995. Ontwikkelingen in de praktische theologie (4). Een kroniek. Praktische Theologie 22(5):607-628.

-, 1999. Practical Theology. Grand Rapids: Eerdmans.

Hendriks, H J 1992. Strategiese beplanning in die gemeente. Wellington: Hugenote.

Hendriks, J 1994. De chaos in de vormgeving van de gemeente. Praktische Theologie 21(4):333-352.

-, 1995. Literatuuroverzicht gemeenteopbouw. Praktische Theologie 22(5), 629653.

Herrmann, J 1994. Patient Kirche. Anmerkungen zur Krise volkskirchlicher Strukturen. Pastoraltheologie 83(10), 468-476.

Hybels, B, Briscoe, S B \& Robinson, H 1989, Mastering contemporary preaching. Portland: Multnomah, 7-16. 
Jackson, B F (Ed. \& Comp.) 1974. You and communication in the church. Waco: Word.

Jongeneel, R A 1994. Zin in werk: een christelijk-politieke visie op arbeid. Nunspeet: Wetenschaplijk Studiecentrum van de Reformatorisch Politieke Federatie.

Kaufman, F X 1979. Kirche begreifen - Analysen und Thesen zur gesellschaftiche Verfassung des Christentums. Freiburg im Breisgau.

Kew, R, White, R 1997. Toward 2015: A church Odyssey. Cambridge, Cowley Mass.

Killinger, J 1995. Preaching to a church in crisis. A Homiletics for the last days of the mainline church. Lima, Ohio: CSS.

Marshall, P 1991. Calling,work, and rest. Potchefstroom: IRS.

McClure, J S 1995. The round table pulpit. Nashville: Abingdon.

Miller, D 1997. Reinventing American Protestantism: Christianity in the New Millennium. Berkeley: University of California.

Morris, D E \& Olsen, C M 1997. Discerning God's will together. Nashville: Upper Room

Neely, A 1993. God's People: A community without walls. The Princeton Seminary Bulletin 14(2):152-161.

Nel, M 1987. Teologiese perspektiewe op gemeentebou. Pretoria: UPTS.

-, 1988. Fases in gemeentebou. Pretoria: UPTS.

-, 1994. Gemeentebou. Half Way House: Orion

-, 1999. Om uit genade te leef. Kaapstad: Struik.

-, 2000. Ek is die verskil. Bloemfontein: CLF.

Nouwen, H J M 1972. The wounded healer: ministry in contemporary society. New York: Doubleday.

Osmer, R R 1990. A teachable spirit. Recovering the teaching office in the church. Louisville: Westminster John Knox.

-, 2001. The teaching ministry in a multicultural world, in Stackhouse, $\mathrm{M} \mathrm{L}$, Browning, D S (eds), 37-75.

Parsons, G \& Leas, S B 1993. Understanding Your Congregation As A System: The Manual. New York: Alban Institute.

Pickard, S K 1999. Liberating evangelism. Harrisburg: Trinity.

Pieterse, H J C 1993. Praktiese Teologie as kommunikatiewe handelingsteorie. Pretoria: RGN.

Raiser, K 1993. Laity in the Ecumenical Movement. Redefining the Profile. Ecumenical Review 45(4):375-383.

Reuter, H 1996. Die Bedeutung der kirchlichen Dienste, Werke und Verbände im Leben der Kirche. Ekklesiologische Überlegungen. Pastoraltheologie 85(1), 33-50.

Roberts, J H 1983. Die brief aan die Efesiërs. Kaapstad: NGK Uitgewers.

Rogers, D M 1989. The minister of youth's calling and characteristics. In Ross, R (comp.) The work of the minister of youth. (Rev Ed.) Nashville: Convention

Ross, R 1989. The work of the minister of youth.(Rev ed) Nashville: Convention.

Roux, G 2000. Wat is die grootste stresfaktore in 'n predikant se lewe? Kruisgewys 1(1):52-53.

Schaller, L 1994. Innovations in ministry. Nashville: Abingdon

-, 1995. The new reformation: Tomorrow arrived yesterday. Nashville: Abingdon.

Schippers, K 1994. Onderweg naar morgen. Praktische Theologie 21(4):393-402. 
Shawhuck, N \& Heuser, R 1993. Leading the congregation. Caring for yourself while serving others. Nashville: Abingdon.

Shelley, M 1989. Introduction. In Hybels, B, Briscoe, S B \& Robinson, H Mastering contemporary preaching. Portland: Multnomah, 7-16.

-, 1995 Changing lives through preaching and worship. Nashville: Moorings.

Stackhouse, M L, Browning, D S (eds.) 2001. The Spirit and the modern Authorities. Volume 2 in die reeks: God and Globalization: Theological ethics and the spheres of life. Harrisburg: Trinity International.

Theron, P F 1995. Theological Training for social transformation in Africa. Missionalia 23(1):45-56.

Van der Geest, H 1981. Presence in the pulpit. The impact of personality in preaching. Atlanta: John Knox. (Vertaal deur Stott, D W uit Duits: Van der Geest, H 1978. Du hast mich angesprochen. Zürich: Theologischer Verlag).

Van Huyssteen, J W 1993. Theology and Science: the Quest for a New Apologetics. The Princeton Seminary Bulletin 14(2):113-133.

-, 1999. The Shaping of Rationality. Toward interdisciplinarity in Theology and Science. Grand Rapids: Eerdmans.

Van Nijen, J J Kan ik mijzelf zijn in de gemeente? De predikantsopleiding en de identiteit van de predikant(e). Praktische Theologie 20(1):43-56.

Van Ruler, A A 1969. Theologisch Werk I. Nijkerk: Callenbach.

-, 1973. Theologisch Werk VI. Nijkerk: Callenbach.

Vos, C J A. 1996. Die Volheid daarvan 1. Pretoria: RGN.

Weber, M 1920. Die Protestantische Ethik und der Geist des Kapitalismus. Gesammelte Aufsätze zur Religionssoziologie 1:17-206. Tübingen.

-, 1991. Der Laie in der Kirche. Grenze und Möglichkeiten. Theologia Practica 26(2):118-122.

Wiersbe, W W 1995. Your preaching is unique. In Shelley, M (ed.) Changing lives through preaching and worship. Nashville: Moorings.

Wimberley, E P 1997. Recalling our own stories. San Francisco: Jossey-Bass

Winkler, E 1993. Mehr als die gesellschaftliche Nützlichkeit vorsieht. Diakonie als Einübung in die Praxis des Glaubens. Diakonie 4, 205-209.

Wuthnow, R 1992. God and Mammon in America. New York: Oxford University Press.

Zijderveld, A C 1971. De abstracte samenleving - Een cultuur-kritische analyse van onze tijd. Meppel. 